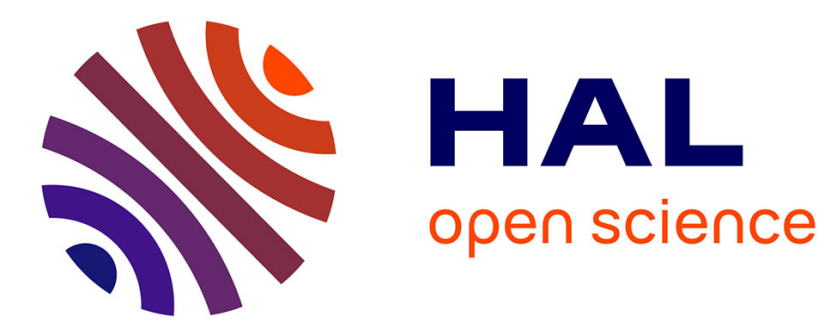

\title{
Monosodium glutamate raises antral distension and plasma amino acid after a standard meal in humans
}

Claire C. Boutry, Hideki H. Matsumoto, Gheorghe G. Airinei, Robert R. Benamouzig, Daniel D. Tomé, Francois F. Blachier, Cecile C. Bos

\section{- To cite this version:}

Claire C. Boutry, Hideki H. Matsumoto, Gheorghe G. Airinei, Robert R. Benamouzig, Daniel D. Tomé, et al.. Monosodium glutamate raises antral distension and plasma amino acid after a standard meal in humans. AJP - Gastrointestinal and Liver Physiology, 2011, 300 (1), pp.G137 - G145. 10.1152/ajpgi.00299.2010 . hal-01000986

\section{HAL Id: hal-01000986 https://hal.science/hal-01000986}

Submitted on 28 May 2020

HAL is a multi-disciplinary open access archive for the deposit and dissemination of scientific research documents, whether they are published or not. The documents may come from teaching and research institutions in France or abroad, or from public or private research centers.
L'archive ouverte pluridisciplinaire HAL, est destinée au dépôt et à la diffusion de documents scientifiques de niveau recherche, publiés ou non, émanant des établissements d'enseignement et de recherche français ou étrangers, des laboratoires publics ou privés. 


\title{
Monosodium glutamate raises antral distension and plasma amino acid after
}

\author{
a standard meal in humans
}

\author{
Claire Boutry, ${ }^{1,2}$ Hideki Matsumoto,${ }^{3}$ Gheorghe Airinei, ${ }^{4}$ Robert Benamouzig,,${ }^{1,2}$ Daniel Tomé,, 2 \\ François Blachier, ${ }^{1,2}$ and Cécile Bos ${ }^{1,2}$ \\ ${ }^{1}$ INRA, Research Center for Human Nutrition-IdF, UMR914 and ${ }^{2}$ AgroParisTech, Research Center for Human Nutrition-IdF, \\ UMR914 Nutrition Physiology and Ingestive Behavior, Paris, France; ${ }^{3}$ AJINOMOTO, Institute of Life Sciences, Amino Acid \\ Basic and Applied Research Group, Kawasaki, Japan; and ${ }^{4}$ Avicenne Hospital, Service of Gastroenterology, Research Center \\ for Human Nutrition-IdF, Bobigny, France
}

Submitted 24 June 2010; accepted in final form 21 October 2010

Boutry C, Matsumoto H, Airinei G, Benamouzig R, Tomé D, Blachier F, Bos C. Monosodium glutamate raises antral distension and plasma amino acid after a standard meal in humans. Am J Physiol Gastrointest Liver Physiol 300: G137-G145, 2011. First published October 28, 2010; doi:10.1152/ajpgi.00299.2010.-The consumption of monosodium glutamate (MSG) is advocated to elicit physiological and metabolic effects, yet these effects have been poorly investigated directly in humans and in particular in the postprandial phase. Thirteen healthy adults were supplemented for 6 days with a nutritional dose of MSG (2 g) or sodium chloride $(\mathrm{NaCl})$ as control, following a crossover design. On the 7 th day, they underwent a complete postprandial examination for the $6 \mathrm{~h}$ following the ingestion of the same liquid standard meal $\left(700 \mathrm{kcal}, 20 \%\right.$ of energy as [ $\left.{ }^{15} \mathrm{~N}\right]$ protein, $50 \%$ as carbohydrate, and $30 \%$ as fat) supplemented with MSG or $\mathrm{NaCl}$. Real-ultrasound measures of antral area indicated a significant increased distension for the $2 \mathrm{~h}$ following the meal supplemented with MSG vs. $\mathrm{NaCl}$. This early postprandial phase was also associated with significantly increased levels of circulating leucine, isoleucine, valine, lysine, cysteine, alanine, tyrosine, and tryptophan after MSG compared with $\mathrm{NaCl}$. No changes to the postprandial glucose, insulin, glucagon-like peptide (GLP)-1, and ghrelin were noted between MSG- and NaCl-supplemented meals. Subjective assessments of hunger and fullness were neither affected by MSG supplementation. Finally, the postprandial fate of dietary $\mathrm{N}$ was identical between dietary conditions. Our findings indicate that nutritional dose of MSG promoted greater postprandial elevations of several indispensable amino acids in plasma and induced gastric distension. Further work to elucidate the possible sparing effect of MSG on indispensable amino acid first-pass uptake in humans is warranted. This trial was registered at clinicaltrials.gov as NCT00862017.

monosodium glutamate; circulating amino acids; gastric antral area; postprandial metabolism; gastric emptying

MONOSODIUM GLUTAMATE (MSG) is a worldwide-used flavor enhancer with a level of consumption that has increased 2.5 times between 1995 and 2007. In this context, it seems important to fully characterize the potential physiological and metabolic effects of this compound. Glutamate is extensively metabolized by enterocytes so dietary glutamate hardly appears in the portal vein (46). Glutamate is a major substrate in enterocytes (4) for energy production and protein metabolism (7). This amino acid is the precursor of metabolites that play important physiological roles, such as

Address for reprint requests and other correspondence: F. Blachier, UMR914 INRA-AgroParisTech Nutrition Physiology and Ingestive Behavior, AgroParisTech, 16 rue Claude Bernard, F-75005 Paris, France (e-mail: blachier @agroparistech.fr). glutathione (oxidative stress modulator) or $\mathrm{N}$-acetylglutamate (metabolic regulator) $(47,55)$. In addition, L-glutamic acid is an excitatory neurotransmitter in the central nervous system and could represent an amino acid with signaling function like leucine that stimulates protein synthesis (17). MSG has been shown to stimulate brush-border membraneassociated enzymatic activities (36) and pancreatic secretions in duodenum (40). Some studies also suggest that glutamate enhances insulin secretion $(1,43)$ and glucose tolerance (1), although this point is controversial (34).

The possible effect of free glutamate on intestinal physiology is suggested by the existence of glutamate receptors in the gastric (41) and intestinal tracts, as well as in the hepatoportal area (42). Glutamate receptors have also been identified in Langerhans islets (20), in the myenteric plexus of the small intestine (50), or in the submucosal plexus in jejunum (31). Thus MSG could have an effect on gastric emptying through these receptors before significant amounts of glutamate are endogenously released through hydrolysis of dietary proteins. The blockade of $N$-methyl-D-aspartate receptors (glutamate receptor) by specific antagonists administered intraperitoneally accelerated gastric emptying (11). An interesting study has reported that MSG supplementation added to a high-energy, high-protein liquid diet accelerated gastric emptying in humans (58). However, a separate study failed to evidence any influence of MSG added to a high-protein meal on satiety in humans (33). Thus no comprehensive set of data is available in humans on the possible effects of MSG supplementation to a standard meal on gastric emptying and on the related effects in terms of satiety and postprandial metabolism.

The aim of this study was then to measure the effects of nutritional doses of MSG in healthy subjects adapted to a standard diet. The known effects of glutamate on the digestive tract principally arise from in vitro or in vivo (animal) studies, making extrapolation of these findings to humans difficult. We chose to study gastric distension as a main outcome because it may represent a determinant of intestinal nutrient delivery and also one of the parameters of intestinal physiology for which validated methods are available. Dietary amino acid appearance kinetics and metabolism, hormonal profiles, and subjective evaluation of hunger and fullness sensation were also studied in parallel to the digestive response. We particularly examined the postprandial metabolism of dietary amino acid because it is closely linked to absorption kinetics $(6,12,15)$. 


\section{MATERIALS AND METHODS}

Subjects. The clinical study was performed in the Research Center for Human Nutrition (CRNH) Ile de France in Avicenne Hospital (Bobigny, France). The study protocol received the approval of the Institutional Review Board of Saint-Germain-en-Laye Hospital. Thirteen healthy subjects ( 7 female, 6 male) were recruited based on the following inclusion criteria: good health status, age between 30 and 50 $\mathrm{yr}$, and body mass index between 23 and $28 \mathrm{~kg} / \mathrm{m}^{2}$. They were included after a thorough medical examination and a routine blood test. All subjects received detailed information on the protocol and gave their written informed consent to participate in the study. All subjects were studied under both the experimental and control conditions following a crossover design. The characteristics of the subjects are depicted on Table 1 . The trial was registered at clinicaltrials.gov (NCT00862017).

Adaptation diets and test meals. The subjects were instructed to follow at home a standard diet providing adequate levels of energy in quantity and quality $\left(33 \mathrm{kcal} \cdot \mathrm{kg}^{-1} \cdot\right.$ day $^{-1}$, with $15 \%$ of energy as protein, $35 \%$ as fat, and $50 \%$ as carbohydrate) for two consecutive periods of 7 days. They received detailed menus depicting the nature and amounts of food for each of the three daily meals. This diet was supplemented daily in MSG ( $2 \mathrm{~g})$ or in an equivalent load of sodium (Na) provided as sodium chloride $(\mathrm{NaCl}, 0.87 \mathrm{~g})$ that was provided to the subjects in two daily doses. They were instructed to spread each capsule of powder on their food at lunch and dinner but were not informed if capsules were containing MSG or $\mathrm{NaCl}$. The subjects were asked to ensure strict compliance with their diets and to complete daily record sheets regarding their food consumption. The rate of compliance was $100 \%$ during all experimental periods. At the end of each dietary adaptation, the subjects attended the CRNH clinical facility at 0900 for a whole experimental day, after an overnight fast. On that day, they received the test meal, composed of $38 \mathrm{~g}$ milk protein (19 $\mathrm{g}$ of casein and $19 \mathrm{~g}$ of milk soluble protein), $27 \mathrm{~g}$ fat (27 $\mathrm{g}$ of commercial oil combining rapeseed, sunflower, grapeseed oils, and Oléisol), $99 \mathrm{~g}$ carbohydrate (79 $\mathrm{g}$ of maltodextrin and $20 \mathrm{~g}$ of saccharose), and water to reach a final volume of $600 \mathrm{ml}$. The test meal provided $700 \mathrm{kcal}$ (20\% energy as protein, 35\% as fat, and $45 \%$ as carbohydrate). The milk proteins were ${ }^{15} \mathrm{~N}$-labeled, as used previously $(25,39)$. The global ${ }^{15} \mathrm{~N}$ isotopic enrichment was 0.5380 atom\%. The test meal was supplemented with MSG (2 g) after the 7-day MSG adaptation period or with $\mathrm{NaCl}(0.87 \mathrm{~g})$ after the 7-day adaptation control period.

Experimental protocol. Each subject was studied the last day of each dietary adaptation (supplemented with MSG or with a $\mathrm{NaCl}$ supplement) following a crossover design. The subjects arrived at the hospital after an overnight fast. After baseline collections of blood and urine samples, they ingested the standard liquid test meal. Blood was sampled at 30-min intervals for the first $3 \mathrm{~h}$ and then at 60-min intervals for the next $3 \mathrm{~h}$. Total urine was collected every $2 \mathrm{~h}$ after the meal ingestion. Transabdominal real-time ultrasound measures of the antral diameter were performed by the same trained experimenter before the meal, just after the subject had finished drinking the meal (10 $\mathrm{min}$ ), and then every $30 \mathrm{~min}$ for the first $3 \mathrm{~h}$ and every hour for the last $3 \mathrm{~h}$. Subjective assessment of hunger, satiety, fullness, and desire to eat was made using 100-mm visual analog scales (VAS) adapted from Hill and Blundell (19). The clinician and the investiga-

Table 1. Baseline characteristics of the subjects

\begin{tabular}{lcc}
\hline \hline & Females & Males \\
\hline Age, yr & $41.9 \pm 3.7$ & $41.8 \pm 4.8$ \\
Height, cm & $160 \pm 2$ & $174 \pm 4$ \\
Body wt, kg & $61.9 \pm 5.0$ & $77.8 \pm 5.3$ \\
BMI, kg/m $\mathrm{m}^{2}$ & $24.2 \pm 1.9$ & $25.7 \pm 1.6$ \\
\hline
\end{tabular}

Results are expressed as means $\pm \mathrm{SD}$. BMI, body mass index. tors involved in the measurement of gastric area and in the assessment of hunger and satiety were blinded regarding the dietary treatment. Briefly, subjects were instructed to rate themselves by marking how they felt at the moment of completing the following questions: Are you hungry? (no-yes); How does your stomach feel? (empty-very full); How many foods can you eat? (nothing-a large amount); and Would you like to eat? (no-yes). The VAS was presented to the subjects before the meal and every hour after the meal. Ratings on the scales were converted to a score $(\mathrm{mm})$ for statistical analysis of their sensations of satiety, fullness, and hunger. Blood samples were centrifuged for $15 \mathrm{~min}$ at $1,500 \mathrm{~g}$, and plasma was separated into aliquots for further analyses. Antiproteases were added to the plasma samples spared for the determination of hormone concentrations. Urine specimens were weighed and separated into aliquots. All the samples were stored at $-20^{\circ} \mathrm{C}$ until analysis.

Measurement of antral gastric distension. The measurement of antral area was used as a parameter related to gastric emptying compared with the standard method scintigraphy $(22,37)$. Measures were performed throughout the experimental day by real-time ultrasound (Logiq Book XP; GE Medical Systems, Velizy, France) in subjects lying down in a supine position. A baseline measure was done just before the meal ingestion at time 0 , and a second measure was performed after the completion of the meal, which slightly varied among subjects (time $=9.5 \pm 4.0 \mathrm{~min}$ ). The antral cross section was then determined every $30 \mathrm{~min}$ for the first $3 \mathrm{~h}$ following the meal ingestion and every hour for the three following hours by a blind trained experimenter. The lower border of the liver and the pancreas served as internal landmarks to determine the longitudinal section $\left(d_{1}\right)$ of the antrum. The lower border of the liver, the aorta, the vena cava, and the gallbladder served to determine the cross section of the antrum $\left(d_{2}\right)$. Antral diameters were computed to determine the antral area, according to the following formula: $\pi \times d_{1} \times d_{2} / 4$. The antral distension was calculated as the antral area at each time expressed as a percentage of the maximal retention measured just after the meal ingestion. Nonlinear regression was applied to determine the half-time of complete distension. The equation used for calculation is given by $y=y O+a \times \exp (-b \times x)$ where $y$ is the antral distension, $x$ is time in min after the meal, and $y 0, a$, and $b$ are constants.

Assessment of the postprandial kinetics of dietary N. The postprandial metabolic fate of ${ }^{15} \mathrm{~N}$-labeled dietary protein was determined through the measures of ${ }^{15} \mathrm{~N}$ enrichment in all of the accessible $\mathrm{N}$ pools: plasma amino acids, protein and urea, urinary urea, and ammonia. The kinetics of appearance of dietary $\mathrm{N}$ in plasma amino acid and urea pools has been shown to directly reflect intestinal absorption kinetics $(6,13)$. Urea and ammonia were isolated from urine and urea, and protein and amino acids were extracted from plasma as previously described (6). The ${ }^{15} \mathrm{~N}$ enrichment was measured by isotope ratio mass spectrometry (Isoprime; GV Instruments, Manchester, UK) coupled to an elemental analyzer (Euro Elemental Analyser 3000; EuroVector, Redavalle, Italy) with atropine as the standard. The metabolic fate of dietary N (expressed as a percentage of the ingested amount) in the different body $\mathrm{N}$ pools monitored (serum proteins and free amino acids, body urea, urinary urea, and ammonia) was calculated as detailed. The incorporation of dietary $\mathrm{N}$ $\left(\mathrm{N}_{\text {inc }}, \%\right.$ ingested $)$ in samples was calculated as $\mathrm{N}_{\text {inc }}=\left[\left(\mathrm{E}_{\text {sample }}-\right.\right.$ $\left.\left.E_{\text {basal }}\right) /\left(E_{\text {meal }}-E_{\text {basal }}\right) \times N_{\text {total }}\right] /\left(N_{\text {ing }} \times 100\right)$ where $E$ refers to enrichment (atom\%), $\mathrm{N}_{\text {total }}$ refers to nitrogen concentration, and $\mathrm{N}_{\text {ing }}$ refers to ingested nitrogen, as previously detailed (13).

Other analytical methods. Urea concentrations in plasma and urine were assayed using a commercial kit (Bio-Mérieux, Marcy l'Etoile, France). Plasma glucose was measured by using a glucose oxidase method (Glucose GOD-DP kit; Kone, Evry, France). Urinary creatinine was assayed by an enzymatic method (Dimension Automate; Dupont de Nemours, Les Ulis, France), and urinary ammonia was measured with an enzymatic method (Kone Automate; Kone). Plasma insulin, glucagons-like peptide (GLP)-1, and ghrelin concentrations were analyzed by using a human endocrine panel (Linco Research, St. 

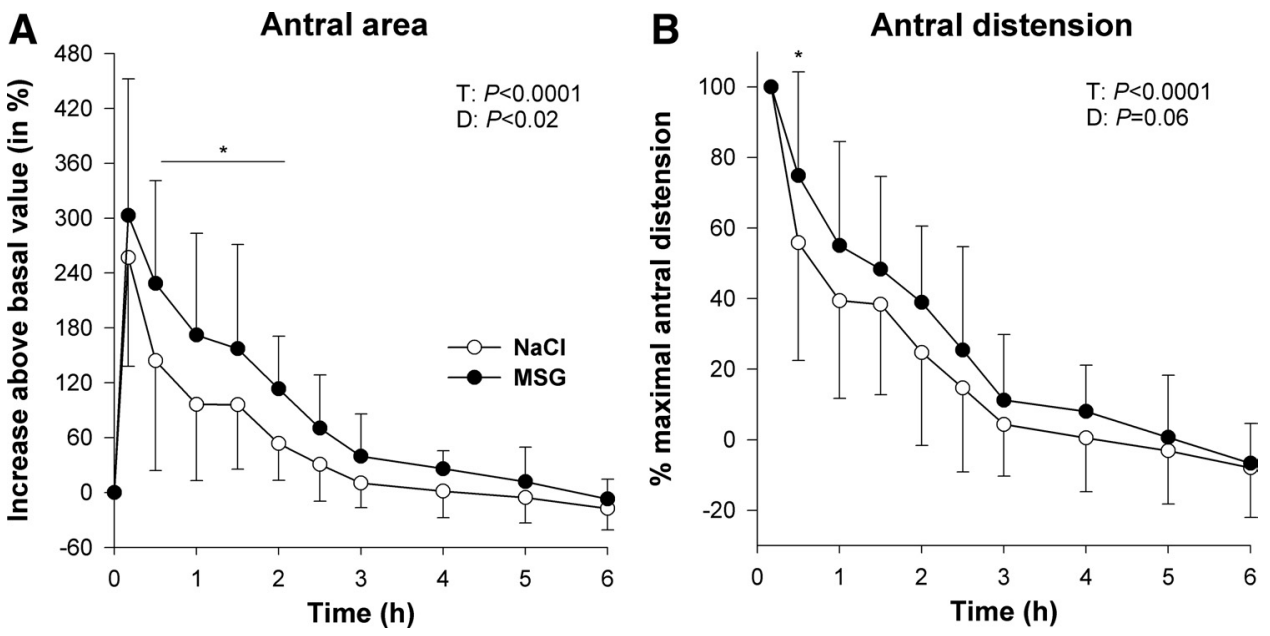

Fig. 1. Effect of monosodium glutamate (MSG) supplementation on time course of antral area $(A)$ and on antral distension $(B)$ after ingestion of a test meal containing $\mathrm{NaCl}$ or MSG in humans ( $n=13$, crossover design). Values are means $\pm \mathrm{SD}$. Time is given as hours from ingestion of the test meal. The main statistical effects [time $(T)$, $\operatorname{diet}(\mathrm{D})$, and their interaction $(T \times \mathrm{D})]$ from a mixed model for repeated measures over time are reported for each variable when $P<$ 0.1 . *Significant difference between $\mathrm{NaCl}$ and MSG at specific time points (post hoc Tukey's test): $P<0.05$.
Charles, MO) on a Bioplex 200 system (Bio-Rad Laboratories, Hercules, CA). Plasma amino acids were analyzed by ion exchange chromatography after protein precipitation, with addition of norleucine as an internal standard (Biotech Instrument, St. Quentin-enYvelines, France).

Statistics. Data are expressed as means \pm SD. Differences in summarized indexes of gastric emptying, area under the curve (AUC), and dietary $\mathrm{N}$ metabolism were tested by using paired $t$-tests. Differences between $\mathrm{MSG}$ and $\mathrm{NaCl}$ supplementations concerning the antral area, metabolite and hormonal postprandial profiles, and postprandial kinetics of dietary $\mathrm{N}$ were analyzed using mixed models for repeatedmeasure analysis, with the treatment and the time as independent, fixed factors and the subject as a random factor (version 9.1; SAS Institute, Cary, NC). For each variable, the most appropriate matrix of covariance structures for random statements was selected. Post hoc tests were performed by using contrast analysis. A $P$ value $<0.05$ was considered as being statistically significant.

\section{RESULTS}

Dietary adaptation and body weight. There was a good compliance of the subjects $(100 \%)$ to the periods of dietary standardization and supplementation with MSG or $\mathrm{NaCl}$. The body weight of the subjects remained stable after both periods $(69.2 \pm 10.2$ and $69.1 \pm 10.2 \mathrm{~kg}$ after $\mathrm{NaCl}$ and $\mathrm{MSG}$ supplementations, respectively). The fasting urea concentration, a marker of protein intake, also remained stable whatever the dietary adaptation $(5.52 \pm 1.90$ and $5.52 \pm 1.13 \mathrm{mmol} / \mathrm{l}$ after $\mathrm{NaCl}$ and MSG supplementations, respectively).

Gastric antral area. Gastric antral area as estimated using the ultrasonographic measurement method was significantly influenced by MSG supplementation. Basal antral areas before the test meal were similar after $\mathrm{NaCl}$ and $\mathrm{MSG}$ supplementation, averaging, respectively, $3.50 \pm 0.83$ and $3.30 \pm 1.06$ $\mathrm{cm}^{2}$. The antral area after the test meal containing MSG was significantly larger than after the control test meal containing $\mathrm{NaCl}$ (diet effect: $P<0.05$ ) (Fig. $1 A$ ). The difference between $\mathrm{NaCl}$ and MSG meals was significant between 30 and $90 \mathrm{~min}$. There was also an effect of MSG addition to the meal on antral distension (diet effect: $P<0.05$ ), significantly at $30 \mathrm{~min}$ (Fig. $1 B)$. The increase of antral area at $30 \mathrm{~min}$ with MSG compared with $\mathrm{NaCl}$ (54\% increase) when $\mathrm{NaCl}$ was first ingested (7 subjects) was not vastly different from the MSG-induced increase of antral area when MSG was first ingested (44\% increase in 6 subjects). AUC for antral area was significantly increased after
MSG compared with $\mathrm{NaCl}$ for the six postprandial hours, with a particularly pronounced effect for the first $3 \mathrm{~h}$ following the meal ingestion (Table 2). Half-time of complete distension was significantly higher after MSG supplementation compared with $\mathrm{NaCl}(+72 \%)$ (Table 2).

Plasma amino acids. MSG supplementation elicited a significant increase in the AUC of plasma concentrations of glutamate, serine, cysteine, isoleucine, leucine, tyrosine, and ornithine (Table 3$)$. There was a trend $(0.1>P>0.05)$ for asparagine, alanine, citrulline, valine, and lysine. These increases were in the range of $10-25 \%$ above the AUC measured in control $(\mathrm{NaCl})$ conditions. For amino acids such as branched-chain amino acids, lysine, tryptophan, tyrosine, or alanine, MSG induced higher plasma concentrations at 60 or 120 min postmeal, and the time course of plasma amino acids was very similar between $\mathrm{MSG}$ and $\mathrm{NaCl}$ conditions afterward (Fig. 2). For amino acids such as glutamate or cysteine, the higher AUC observed after MSG supplementation compared with $\mathrm{NaCl}$ was more constant throughout the postprandial period. Glutamine concentrations were not significantly modified by the dietary treatment.

Transfer of dietary $N$ into plasma amino acids, urea, and proteins, and urinary ammonia and urea. The MSG supplementation had no significant effect on kinetics of dietary $\mathrm{N}$ in plasma, since there was no significant difference in the time course of appearance of dietary $\mathrm{N}$ into plasma amino acids after $\mathrm{MSG}$ or $\mathrm{NaCl}$ supplementation, which peaked in both

Table 2. Effect of MSG supplementation on the AUC obtained after measure of antral area by real-time ultrasound

\begin{tabular}{lccc}
\hline \hline & $\mathrm{NaCl}$ & MSG & Stat Effect* \\
\hline Antral area, $\mathrm{cm}^{2}$ & & & \\
AUC $0-180$ & $1,134 \pm 198$ & $1,334 \pm 356$ & $P=0.05$ \\
AUC $_{0-360}$ & $1,724 \pm 209$ & $1,984 \pm 403$ & $P<0.05$ \\
Antral area, \%baseline value & & & \\
AUC $_{0-180}$ & $504 \pm 241$ & $739 \pm 366$ & $P<0.05$ \\
AUC $_{0-360}$ & $463 \pm 324$ & $795 \pm 487$ & $P<0.05$ \\
$T_{1 / 2}$ complete distension, min & $52.7 \pm 32.0$ & $90.6 \pm 41,9$ & $P<0.05$ \\
\hline
\end{tabular}

Results are expressed as means $\pm \mathrm{SD} ; n=13$ subjects, crossover design. MSG, monosodium glutamate; AUC, area under the curve; 0-180, 0-180 min; 0-360, 0-360 min; $T_{1 / 2}$, half-time. *Paired Student's test. 
Table 3. AUC of plasma amino acid concentrations after ingestion of a test meal containing NaCl or MSG in humans

\begin{tabular}{|c|c|c|c|c|}
\hline & $\mathrm{NaCl}$ & MSG & Change, $\%$ & Stat Effect* \\
\hline Tau & $394 \pm 107$ & $441 \pm 114$ & 11.9 & NS \\
\hline Asp & $104 \pm 37$ & $107 \pm 37$ & 2.6 & NS \\
\hline Thr & $909 \pm 354$ & $1,021 \pm 396$ & 12.3 & NS \\
\hline Asn & $1,059 \pm 376$ & $1,180 \pm 428$ & 11.5 & $P=0.09$ \\
\hline Glu & $407 \pm 106$ & $451 \pm 109$ & 10.8 & $P<0.005$ \\
\hline Gln & $1,656 \pm 436$ & $1,802 \pm 611$ & 8.8 & NS \\
\hline Cys & $99 \pm 34$ & $124 \pm 46$ & 24.9 & $P<0.005$ \\
\hline Val & $1,427 \pm 262$ & $1,542 \pm 316$ & 8.1 & $P=0.07$ \\
\hline Met & $146 \pm 39$ & $160 \pm 45$ & 9.5 & NS \\
\hline Ile & $448 \pm 81$ & $513 \pm 119$ & 14.4 & $P<0.05$ \\
\hline Leu & $956 \pm 189$ & $1,064 \pm 231$ & 11.3 & $P<0.05$ \\
\hline Tyr & $384 \pm 88$ & $449 \pm 106$ & 16.7 & $P<0.05$ \\
\hline Arg & $556 \pm 185$ & $584 \pm 161$ & 5.0 & NS \\
\hline Pro & $1,505 \pm 427$ & $1,596 \pm 554$ & 6.0 & NS \\
\hline Total AA & $16,752 \pm 3,608$ & $18,438 \pm 4,411$ & 10.1 & $P=0.06$ \\
\hline Indispensable AA & $6,197 \pm 1,326$ & $6,795 \pm 1,579$ & 9.6 & $P<0.05$ \\
\hline Dispensable AA & $10,555 \pm 2,359$ & $11,643 \pm 2,886$ & 10.3 & $P=0.08$ \\
\hline Neoglucogenic AA $\dagger$ & $6,837 \pm 1,815$ & $7,591 \pm 2,162$ & 11.0 & $P=0.08$ \\
\hline Branched-chain AA & $2,831 \pm 516$ & $3,119 \pm 643$ & 10.2 & $P<0.05$ \\
\hline
\end{tabular}

Results are expressed as means $\pm \mathrm{SD} ; n=13$ subjects, crossover design. Values are expressed in $\mu \mathrm{mol} / 6 \mathrm{~h}$. AA, amino acid; NS, not significant. *Paired Student's test. $†$ Sum of glutamate, glutamine, alanine, serine, threonine, and glycine concentrations. $\ddagger$ Sum of valine, leucine, and isoleucine concentrations.

cases $4 \mathrm{~h}$ after the meal at $0.37-0.40 \%$ of the ingested dose (Fig. 3A). Consistently, the incorporation of dietary nitrogen into plasma urea was not influenced by MSG supplementation (Fig. 3B). There was also no significant difference in the incorporation of dietary nitrogen into other $\mathrm{N}$-accessible pools (plasma proteins, urinary ammonia, and urea). The transfer of dietary $\mathrm{N} 6 \mathrm{~h}$ after the meal to plasma protein was $12.8 \pm 4.4 \%$ of ingested and $11.7 \pm 1.7 \%$ of ingested for $\mathrm{NaCl}$ and MSG, respectively. For urinary ammonia, it was $0.30 \pm 0.19$ and $0.29 \pm$ $0.15 \%$ of ingested for $\mathrm{NaCl}$ and MSG, respectively, and for urinary urea it was $10.5 \pm 4.4$ and $11.9 \pm 3.2 \%$ of ingested for $\mathrm{NaCl}$ and MSG, respectively. Deamination of dietary amino acids was not affected by MSG supplementation.

Plasma glucose and hormones and hunger-related perceived sensations. There was no significant effect of MSG supplementation on glycemia (Fig. 4A). Plasma insulin (Fig. 4B), GLP-1 (Fig. 4C), and ghrelin (Fig. 4D) concentrations were not significantly influenced by MSG supplementation during $6 \mathrm{~h}$ after the meal in humans. Following the ingestion of the standard meal, the MSG supplementation had no significant effect on the perception of hunger and fullness, despite a trend toward a significant interaction between time and treatment on hunger sensation (Fig. 5). The prospective food consumption and perceived pleasure curves were similar to that obtained for hunger (data not shown).

\section{DISCUSSION}

This randomized cross-over trial in dietary-controlled, healthy subjects revealed that MSG added at nutritional doses to a standard diet elicited an antral distension and an elevation of plasma concentrations of several amino acids, including branched-chain amino acids, in the early postprandial phase. These physiological and metabolic effects were not associated with significant change in the metabolic fate of dietary $\mathrm{N}$, the postprandial glucose and hormonal responses, and the gastrointestinal sensations of hunger and fullness.

The gastric distension following ingestion of a liquid, balanced meal providing approximately one-third of the daily energy intake was more pronounced in subjects receiving MSG at doses close to that commonly consumed than an equivalent dose of $\mathrm{NaCl}$ as control. The monitoring of antral area by two-dimension real-time ultrasound before and at regular intervals following the ingestion of the test meal has been proposed to represent a method to assess gastric emptying $(5,22)$, and the specific ultrasonographic monitoring of the antrum cross-sectional area is known to accurately detect variations in gastric volume $(44,48)$. MSG ingestion elicited an $18 \%$ higher AUC of antrum for the first $3 \mathrm{~h}$ after the meal ingestion. However, it is not obvious that the antral distension observed in our study after the MSGsupplemented meal really reflected a change in meal gastric emptying. Indeed, our results may rather be explained as a MSG-induced enhanced gastric secretion without increased gastric emptying resulting in increased antral distension. Our results are in contrast with that of the only available study that has evaluated the effect of MSG supplementation on gastric emptying using an oral dose of $\left[{ }^{13} \mathrm{C}\right]$ sodium acetate (58). Using this latter method, the authors reported an acceleration of gastric emptying after MSG supplementation added to a protein-rich liquid diet, but no effect was observed when MSG was added to a carbohydrate-rich diet or to the same volume of water. Different hypotheses can be 

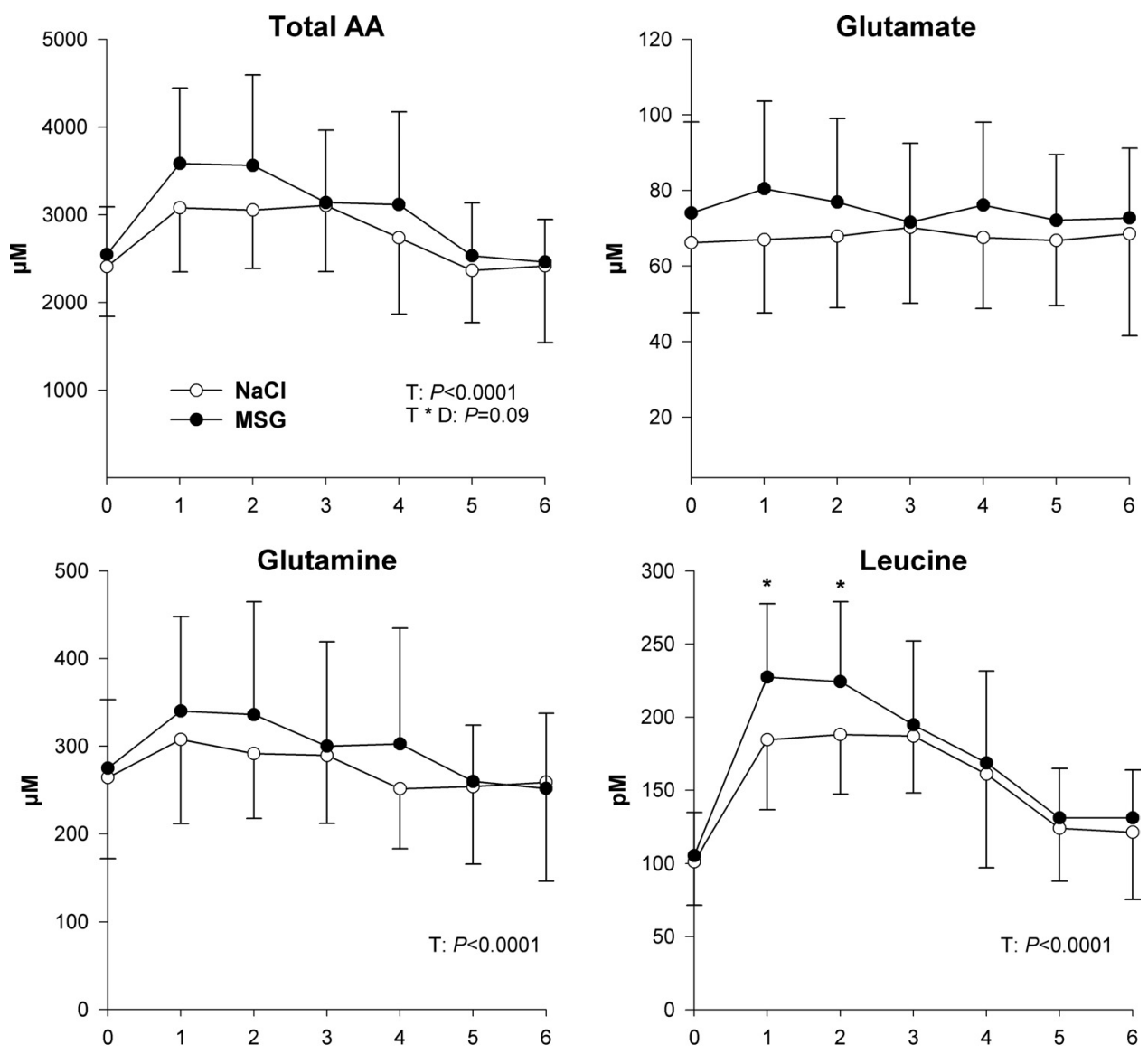

Fig. 2. Plasma concentrations of total amino acids (AA), glutamate, glutamine, leucine, lysine, and cysteine after ingestion of a test meal containing $\mathrm{NaCl}$ or MSG in humans $(n=$ 13 , crossover design). Values are means \pm $\mathrm{SD}$. Time is given as hours from ingestion of the test meal. The main statistical effects $(T, \mathrm{D}$, and $T \times \mathrm{D}$ ) from a mixed model for repeated measures over time are reported for each variable when $P<0.1$. *Significant difference between $\mathrm{NaCl}$ and MSG at specific time points (post hoc Tukey's test): $P<0.05$.
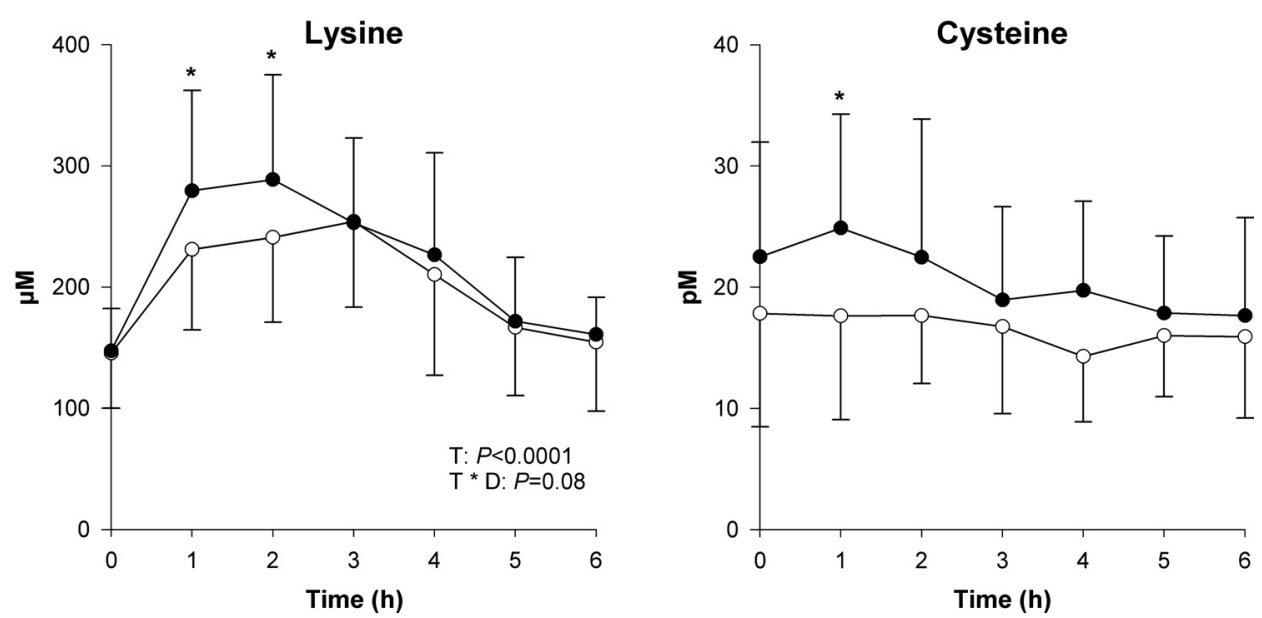

advanced to explain the discrepancy between Zai et al.'s (58) findings and the present results. We used a meal that contained more energy (700 vs. $400 \mathrm{kcal})$ and represented a larger volume (600 vs. $400 \mathrm{ml}$ ) than the meal used in their study, and both parameters are likely to influence gastric emptying (28). The concentration of MSG was lower in our study (16 vs. $30 \mathrm{mmol} / \mathrm{l})$. Moreover, the protein source used in the study by Zai et al. was casein, whereas we used total milk proteins (35). Last but not least, as reported above, Zai et al. used $\left[{ }^{13} \mathrm{C}\right]$ sodium acetate administration to measure gastric emptying while we used ultrasonographic monitoring of the antrum area.
Animal studies have been performed to assess the direct effect of MSG supplementation on gastric emptying or intestinal peristaltism. Toyomasu et al. (54) have shown stimulation of the upper gut motility through the vagus nerve after intragastric MSG stimulation, an effect that was associated with an acceleration of the gastric emptying rate. Furthermore, injection of MSG in stomach, duodenum, and portal vein increases gastric vagal afferent activity in rats $(42,56)$. However, it is worth noting that experimental conditions in animal and human studies are often very different, thus complicating comparison on the effects of MSG in these situations. 
Fig. 3. Systemic utilization of dietary N. N incorporation into plasma amino acid $(A)$ and urea $(B)$ after ingestion of a test meal containing $\mathrm{NaCl}$ or MSG in humans $(n=13$, crossover design). Values are means $\pm \mathrm{SD}$. Time is given as hours from ingestion of the test meal.
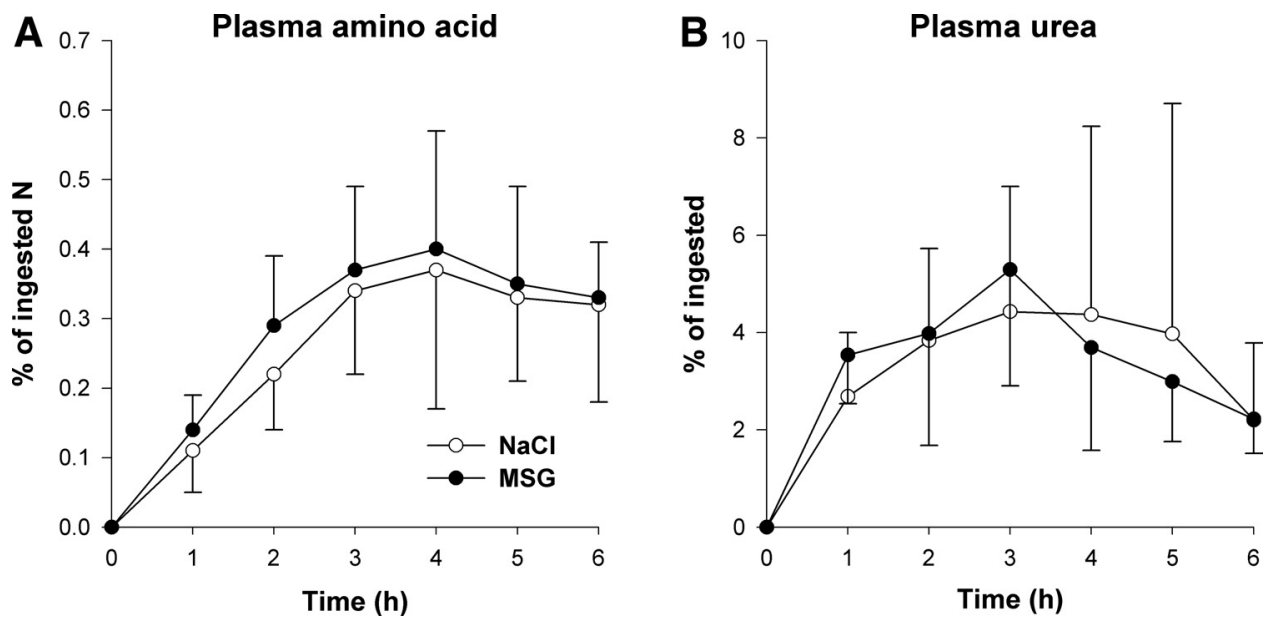

An interesting finding of the present study was the transient rise in plasma concentrations of many amino acids when subjects ingested the MSG-supplemented meal. This effect concerned in particular branched-chain amino acids, with significant $20-25 \%$ increases of circulating concentrations of leucine and isoleucine at 1 and $2 \mathrm{~h}$ after the meal. Branched-chain amino acid systemic availability has consistently been found to be increased in animals supplemented with MSG (24, 26, 30). This effect suggests a sparing effect of MSG on branched-chain amino acid firstpass uptake, through the implication of glutamate in reducing branched-chain amino acid transamination. Recently, enterocytes isolated from pig jejunum have been shown to extensively transaminate branched-chain amino acids, a phenomenon that is stimulated by $\alpha$-ketoglutarate (8). In humans, leucine first-pass uptake may represent $13-37 \%$ of the dietary leucine intake $(2,10,21,23,38)$, and it is conceivable that decreased transamination might translate
Fig. 4. Plasma concentrations of glucose $(A)$, insulin $(B)$, glucagon-like peptide (GLP)-1 (C), and grhelin $(D)$ after ingestion of a test meal containing $\mathrm{NaCl}$ or MSG in humans $(n=13$, crossover design). Values are means $\pm \mathrm{SD}$. Time is given as hours from ingestion of the test meal.
A

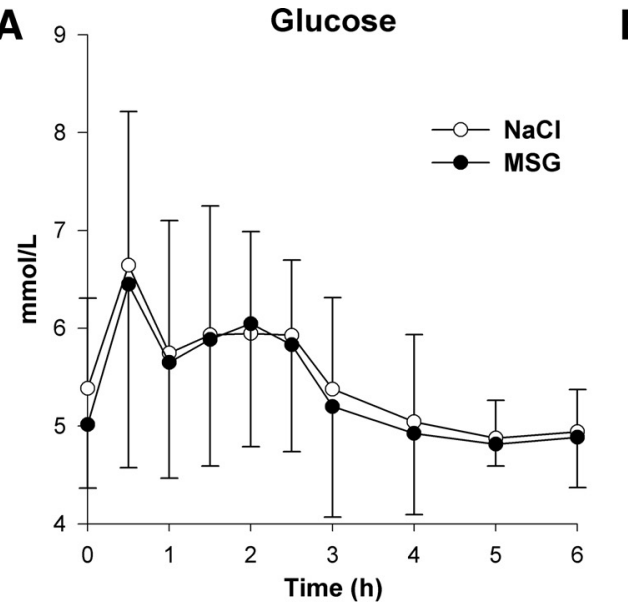

C

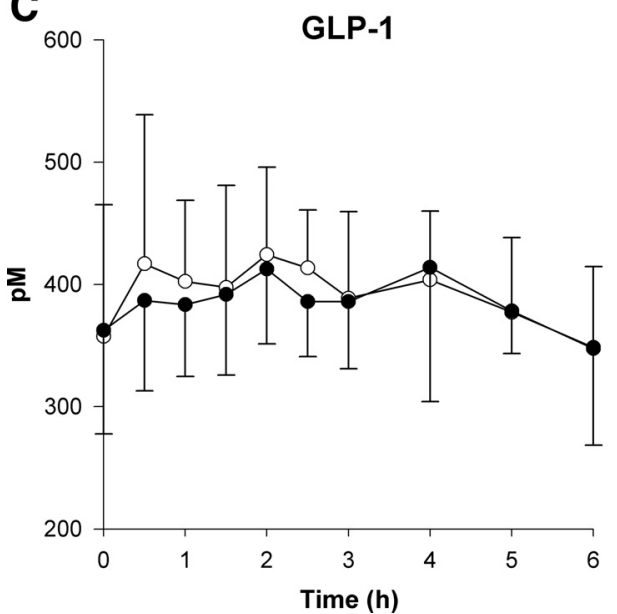

B

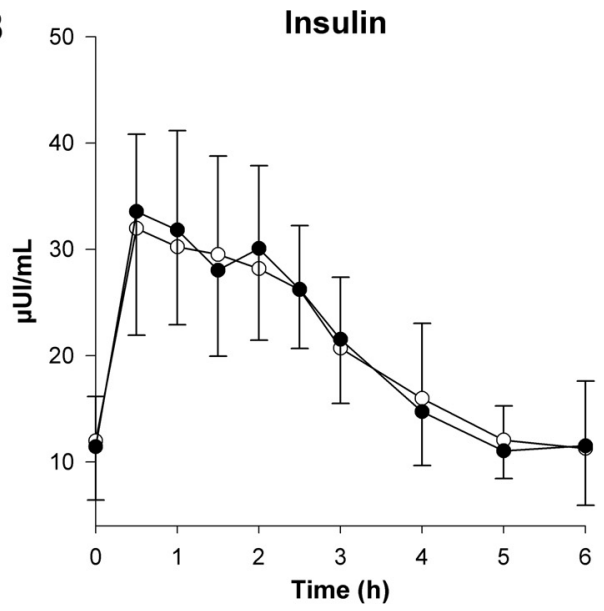

D

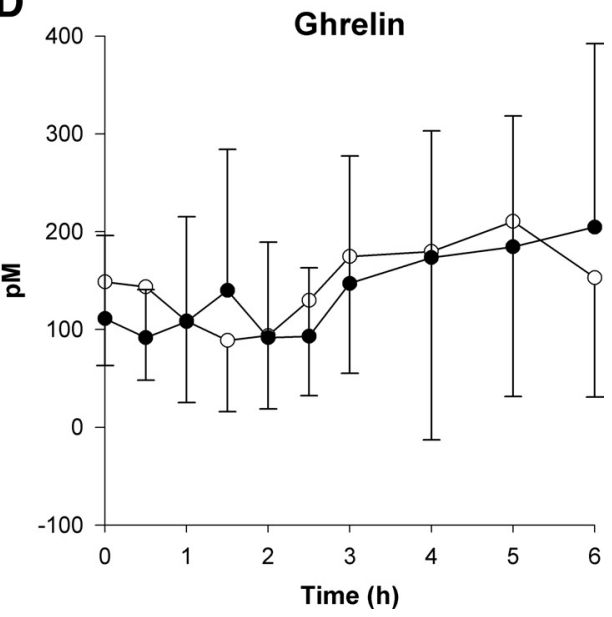


A

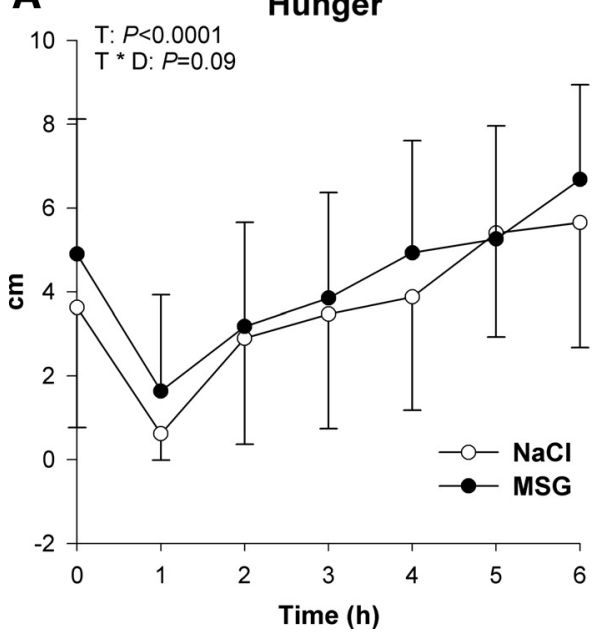

B

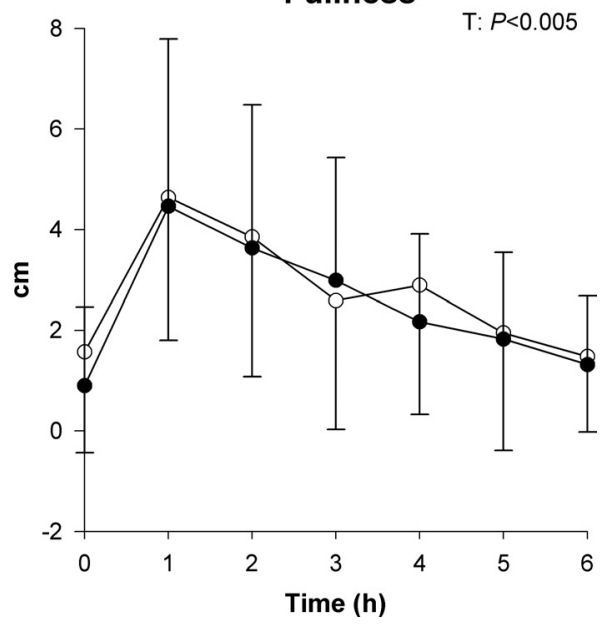

Fig. 5. Effect of MSG supplementation on perception of fullness $(B)$ and hunger $(A)$ after ingestion of a test meal containing $\mathrm{NaCl}$ or MSG in humans $(n=13$, crossover design). Values are means $\pm \mathrm{SD}$. Time is given as hours from ingestion of the test meal. The main statistical effects $(T, \mathrm{D}$, and $T \times \mathrm{D})$ from a mixed model for repeated measures over time are reported for each variable when $P<0.1$. into elevation of plasma concentrations. Increased postprandial glutamatemia, although of mild amplitude (11\% increase of the postprandial AUC), is in line with previous results obtained in humans $(51,52)$.

We also found an increase in other amino acids that are derived from glutamate, including ornithine, citrulline, and alanine, in accord with other studies $(24,26,30,53)$ and with the known capacity of isolated enterocytes to convert glutamate into ornithine and citrulline and to allow pyruvate transamination into alanine (3). In contrast, this study did not demonstrate a significant increase in glutamine, aspartate, proline, or arginine as previously reported $(24,51)$. Last, since the catabolism of cysteine and tyrosine involves transamination with $\alpha$-ketoglutarate being converted to glutamate, it is conceivable that glutamate through a mere mass-action phenomenon would participate in the sparing of these amino acids and thus in their increased plasma concentration. Data obtained in pigs from arteriovenous differences in tyrosine plasma concentrations suggest that this amino acid is little degraded by the intestine in this experimental model (57). Regarding cysteine catabolism, from the low appearance of this amino acid in the portal blood ( $<20 \%$ of dietary intake), it has been suggested that piglet intestine extensively utilizes cyst(e)ine (49), a suggestion that is in line with the capacity of isolated enterocytes to catabolize this amino acid (9).

By contrast with the effects on aminoacidemia, we could not evidence any detectable difference in the postprandial metabolic fate of dietary proteins, whether the subjects ingested the meal with or without MSG. The ${ }^{15} \mathrm{~N}$-labeled protein was used in the experimental meals because we have previously shown that the postprandial appearance of dietary $\mathrm{N}$ in pools such as plasma amino acids or urea is very sensitive to the kinetics of intestinal delivery of dietary proteins $(6,13,16,29)$. Because the measure of postprandial dietary $\mathrm{N}$ retention gives a global picture of protein metabolism, we cannot infer from our results that protein synthesis and/or degradation rates were unaffected by the dietary treatment but only that the net utilization of dietary $\mathrm{N}$ was similar. The discrepancy between the MSGinduced increase in plasma amino acids and the absence of effect of MSG on dietary $\mathrm{N}$ appearance in plasma amino acids and urea indicates that the improved systemic availability of amino acids may rather be the result of a modified first-pass uptake than the result of changes in protein fluxes. However, it would be necessary to perform studies with tracers to clarify this point.

GLP-1 and ghrelin are two gastrointestinal hormones that are potent regulators of gastric emptying (18). However, in this study, postprandial GLP-1 and ghrelin concentrations were not significantly influenced by dietary MSG, and there was no clear association between these hormones and the functional response observed at the gastric level. The glucose and insulin postprandial responses were also unaffected by MSG, which is in accord with the GLP-1 results. Collectively, our results are in agreement with the only study that has assessed the effect of MSG $(0.6 \%)$ administration to a high-protein meal on satiety, energy intake, and hormone circulating concentrations in humans (33). Accordingly, the MSG ingestion was not associated with any changes to the postprandial gastrointestinal sensations (fullness, hunger). Despite crossover design, our study may have lacked power to detect subtle changes in such sensations because visual analog scales represent a technique with high intersubject variability. Moreover, if modifications of the gastric volume are one component that intervenes in the sensations of fullness and hunger after a meal, they are not always sufficient to induce changes to satiety and hunger feelings (45).

In conclusion, we show that MSG supplementation at nutritional doses elicits in healthy humans a postprandial gastric distension and an elevation of several amino acid plasma concentrations that are possibly linked. These physiological and metabolic effects had, however, no measurable consequences in terms of satiety, hormone profiles, or dietary $\mathrm{N}$ metabolism. Thus, it can be hypothesized that the gastric distension did not translate into a delay of gastric emptying. The mechanisms involved in such distension are not known but may involve an increased water or acid secretion in the stomach in response to $\mathrm{MSG}$ supplementation. A recent study showing the stimulation of gastric acid secretion by MSG in dogs is in accordance with this hypothesis (59). Moreover, intraduodenal, but not intrajejunal, infusion of amino acids stimulates gastric secretion (32). Intravenous infusion of amino acids is also able to have this latter effect and acts on both acid and pepsin secretion (27). Our findings call for further studies to elucidate the mechanisms by which dietary glutamate impact systemic amino acid concentrations and the consequences of 
such modulations. Last, it is worth noting that, in the present study, amino acid concentrations were measured in blood plasma but not in erythrocytes, which can contribute to the interorgan transfer of amino acids (14). However, although some amino acids are highly concentrated in erythrocytes, it is generally considered that the exchanges with plasma proceed very slowly, and thus this intracellular pool is considered to contribute poorly to interorgan fluxes.

\section{ACKNOWLEDGMENTS}

We thank Marie-Claude Amard for assistance in volunteers' recruitment, Juliane Calvez for help with visual analogic scales, and Catherine Luengo and Véronique Mathé for technical assistance. We acknowledge Jacques Fauquant (STLO laboratory, Rennes, France) for labeled milk proteins.

\section{GRANTS}

The project was supported by Ajinomoto (Japan) and by grants from the National Institute for Agronomic Research (INRA, France).

\section{DISCLOSURES}

None of the authors had a conflict of interest.

\section{REFERENCES}

1. Bertrand G, Puech R, Loubatieres-Mariani MM, Bockaert J. Glutamate stimulates insulin secretion and improves glucose tolerance in rats. Am J Physiol Endocrinol Metab 269: E551-E556, 1995.

2. Biolo G, Tessari P, Inchiostro S, Bruttomesso D, Fongher C, Sabadin L, Fratton MG, Valerio A, Tiengo A. Leucine and phenylalanine kinetics during mixed meal ingestion: a multiple tracer approach. Am J Physiol Endocrinol Metab 262: E455-E463, 1992.

3. Blachier F, Boutry C, Bos C, Tome D. Metabolism and functions of L-glutamate in the epithelial cells of the small and large intestines. Am J Clin Nutr 90: 814S-821S, 2009.

4. Blachier F, Guihot-Joubrel G, Vaugelade P, Le Boucher J, Bernard F, Duee P, Cynober L. Portal hyperglutamatemia after dietary supplementation with monosodium glutamate in pigs. Digestion 60: 349-357, 1999.

5. Bolondi L, Bortolotti M, Santi V, Calletti T, Gaiani S, Labo G. Measurement of gastric emptying time by real-time ultrasonography. Gastroenterology 89: 752-759, 1985.

6. Bos C, Metges CC, Gaudichon C, Petzke KJ, Pueyo ME, Morens C, Everwand J, Benamouzig R, Tome D. Postprandial kinetics of dietary amino acids are the main determinant of their metabolism after soy or milk protein ingestion in humans. J Nutr 133: 1308-1315, 2003.

7. Burrin DG, Stoll B. Metabolic fate and function of dietary glutamate in the gut. Am J Clin Nutr 90: 8505-8565, 2009.

8. Chen L, Li P, Wang J, Li X, Gao H, Yin Y, Hou Y, Wu G. Catabolism of nutritionally essential amino acids in developing porcine enterocytes. Amino Acids 37: 143-152, 2009.

9. Coloso RM, Stipanuk MH. Metabolism of cyst (e) ine in rat enterocytes. J Nutr 119: 1914-1924, 1989.

10. Cortiella J, Matthews DE, Hoerr RA, Bier DM, Young VR. Leucine kinetics at graded intakes in young men: quantitative fate of dietary leucine. Am J Clin Nutr 48: 998-1009, 1988.

11. Covasa M, Ritter RC, Burns GA. NMDA receptor participation in control of food intake by the stomach. Am J Physiol Regul Integr Comp Physiol 278: R1362-R1368, 2000.

12. Dangin M, Boirie Y, Garcia-Rodenas $\mathbf{C}$, Gachon $\mathbf{P}$, Fauquant $\mathbf{J}$, Callier P, Ballevre O, Beaufrere B. The digestion rate of protein is an independent regulating factor of postprandial protein retention. Am J Physiol Endocrinol Metab 280: E340-E348, 2001.

13. Deglaire A, Fromentin C, Fouillet H, Airinei G, Gaudichon C, Boutry C, Benamouzig R, Moughan PJ, Tome D, Bos C. Hydrolyzed dietary casein as compared with the intact protein reduces postprandial peripheral, but not whole-body, uptake of nitrogen in humans. Am J Clin Nutr 90: 1011-1022, 2009.

14. Felig P, Wahren J, Raf $\mathbf{L}$. Evidence of inter-organ amino-acid transport by blood cells in humans. Proc Natl Acad Sci USA 70: 1775-1779, 1973.

15. Fouillet H, Juillet B, Gaudichon C, Mariotti F, Tome D, Bos C. Absorption kinetics are a key factor regulating postprandial protein metabolism in response to qualitative and quantitative variations in protein intake. Am J Physiol Regul Integr Comp Physiol 297: R1691-R1705, 2009.

16. Fouillet H, Mariotti F, Gaudichon C, Bos C, Tome D. Peripheral and splanchnic metabolism of dietary nitrogen are differently affected by the protein source in humans as assessed by compartmental modeling. J Nutr 132: 125-133, 2002.

17. Garlick PJ. The role of leucine in the regulation of protein metabolism. J Nutr 135: 1553S-1556S, 2005.

18. Hellstrom PM, Gryback P, Jacobsson H. The physiology of gastric emptying. Best Pract Res Clin Anaesthesiol 20: 397-407, 2006.

19. Hill AJ, Blundell JE. Nutrients and behaviour: research strategies for the investigation of taste characteristics, food preferences, hunger sensations and eating patterns in man. J Psychiatr Res 17: 203-212, 1982.

20. Hinoi E, Takarada T, Ueshima T, Tsuchihashi Y, Yoneda Y. Glutamate signaling in peripheral tissues. Eur J Biochem 271: 1-13, 2004.

21. Hoerr RA, Matthews DE, Bier DM, Young VR. Leucine kinetics from $\left[{ }^{2} \mathrm{H}_{3}\right]-$ and $\left[{ }^{13} \mathrm{C}\right]$ leucine infused simultaneously by gut and vein. $\mathrm{Am} \mathrm{J}$ Physiol Endocrinol Metab 260: E111-E117, 1991.

22. Holt S, Cervantes J, Wilkinson AA, Wallace JH. Measurement of gastric emptying rate in humans by real-time ultrasound. Gastroenterology 90: 918-923, 1986.

23. Horber FF, Haymond MW. Human growth hormone prevents the protein catabolic side effects of prednisone in humans. J Clin Invest 86: 265-272, 1990.

24. Janeczko MJ, Stoll B, Chang X, Guan X, Burrin DG. Extensive gut metabolism limits the intestinal absorption of excessive supplemental dietary glutamate loads in infant pigs. J Nutr 137: 2384-2390, 2007.

25. Juillet B, Fouillet H, Bos C, Mariotti F, Gausseres N, Benamouzig R, Tome D, Gaudichon C. Increasing habitual protein intake results in reduced postprandial efficiency of peripheral, anabolic wheat protein nitrogen use in humans. Am J Clin Nutr 87: 666-678, 2008.

26. Kawamata Y, Kuwahara T, Kodama R, Yoneda Y, Torii K, Sakai R. Dietary glutamic acid increased postprandial availability of alanine and branched-chain amino acids in rats (Abstract). Clin Nutr Suppl 3: 221, 2008.

27. Konturek SJ, Kwiecien N, Obtulowicz W, Mikos E, Sito E, Oleksy J. Comparison of intraduodenal and intravenous administration of amino acids on gastric secretion in healthy subjects and patients with duodenal ulcer. Gut 19: 859-864, 1978.

28. Kwiatek MA, Menne D, Steingoetter A, Goetze O, Forras-Kaufman Z, Kaufman E, Fruehauf H, Boesiger P, Fried M, Schwizer W, Fox MR. Effect of meal volume and calorie load on postprandial gastric function and emptying: studies under physiological conditions by combined fiberoptic pressure measurement and MRI. Am J Physiol Gastrointest Liver Physiol 297: G894-G901, 2009.

29. Lacroix M, Bos C, Leonil J, Airinei G, Luengo C, Dare S, Benamouzig R, Fouillet H, Fauquant J, Tome D, Gaudichon C. Compared with casein or total milk protein, digestion of milk soluble proteins is too rapid to sustain the anabolic postprandial amino acid requirement. Am J Clin Nutr 84: 1070-1079, 2006.

30. Lambert BD, Filip R, Stoll B, Junghans P, Derno M, Hennig U, Souffrant WB, Pierzynowski S, Burrin DG. First-pass metabolism limits the intestinal absorption of enteral alpha-ketoglutarate in young pigs. J Nutr 136: 2779-2784, 2006.

31. Larzabal A, Losada J, Mateos JM, Benitez R, Garmilla IJ, Kuhn R, Grandes P, Sarria R. Distribution of the group II metabotropic glutamate receptors $(\mathrm{mGluR} 2 / 3)$ in the enteric nervous system of the rat. Neurosci Lett 276: 91-94, 1999.

32. Lenz HJ, Hogan DL, Isenberg JI. Intestinal phase of gastric acid secretion in humans with and without portacaval shunt. Gastroenterology 89: 791-796, 1985.

33. Luscombe-Marsh ND, Smeets AJ, Westerterp-Plantenga MS. The addition of monosodium glutamate and inosine monophosphate-5 to highprotein meals: effects on satiety, and energy and macronutrient intakes. $\mathrm{Br}$ J Nutr 102: 929-937, 2009.

34. MacDonald MJ, Fahien LA. Glutamate is not a messenger in insulin secretion. J Biol Chem 275: 34025-34027, 2000.

35. Mahe S, Roos N, Benamouzig R, Sick H, Baglieri A, Huneau JF, Tome D. True exogenous and endogenous nitrogen fractions in the human jejunum after ingestion of small amounts of $15 \mathrm{~N}$-labeled casein. $J$ Nutr 124: 548-555, 1994.

36. Martinkova A, Lenhardt L, Mozes S. Effect of neonatal MSG treatment on day-night alkaline phosphatase activity in the rat duodenum. Physiol Res 49: 339-345, 2000. 
37. Marzio L, Giacobbe A, Conoscitore P, Facciorusso D, Frusciante V, Modoni S. Evaluation of the use of ultrasonography in the study of liquid gastric emptying. Am J Gastroenterol 84: 496-500, 1989.

38. Matthews DE, Marano MA, Campbell RG. Splanchnic bed utilization of leucine and phenylalanine in humans. Am J Physiol Endocrinol Metab 264: E109-E118, 1993.

39. Morens C, Bos C, Pueyo ME, Benamouzig R, Gausseres N, Luengo C, Tome D, Gaudichon C. Increasing habitual protein intake accentuates differences in postprandial dietary nitrogen utilization between protein sources in humans. J Nutr 133: 2733-2740, 2003.

40. Naim M, Ohara I, Kare MR, Levinson M. Interaction of MSG taste with nutrition: perspectives in consummatory behavior and digestion. Physiol Behav 49: 1019-1024, 1991.

41. Niijima A. Effects of oral and intestinal stimulation with umami substance on gastric vagus activity. Physiol Behav 49: 1025-1028, 1991.

42. Niijima A. Reflex effects of oral, gastrointestinal and hepatoportal glutamate sensors on vagal nerve activity. J Nutr 130: 971S-973S, 2000.

43. Niijima A, Togiyama T, Adachi A. Cephalic-phase insulin release induced by taste stimulus of monosodium glutamate (umami taste). Physiol Behav 48: 905-908, 1990.

44. Perlas A, Chan VW, Lupu CM, Mitsakakis N, Hanbidge A. Ultrasound assessment of gastric content and volume. Anesthesiology 111: 82-89, 2009.

45. Read N, French S, Cunningham $\mathbf{K}$. The role of the gut in regulating food intake in man. Nutr Rev 52: 1-10, 1994.

46. Reeds PJ, Burrin DG, Stoll B, Jahoor F. Intestinal glutamate metabolism. J Nutr 130: 978S-982S, 2000.

47. Reeds PJ, Burrin DG, Stoll B, Jahoor F, Wykes L, Henry J, Frazer ME. Enteral glutamate is the preferential source for mucosal glutathione synthesis in fed piglets. Am J Physiol Endocrinol Metab 273: E408-E415, 1997.

48. Ricci R, Bontempo I, Corazziari E, La Bella A, Torsoli A. Real time ultrasonography of the gastric antrum. Gut 34: 173-176, 1993.

49. Shoveller AK, Stoll B, Ball RO, Burrin DG. Nutritional and functional importance of intestinal sulfur amino acid metabolism. J Nutr 135: $1609-1612,2005$
50. Sinsky M, Donnerer J. Evidence for a neurotransmitter role of glutamate in guinea pig myenteric plexus neurons. Neurosci Lett 258: 109-112, 1998.

51. Stegink LD, Filer LJ Jr, Baker GL. Plasma amino acid concentrations in normal adults fed meals with added monosodium L-glutamate and aspartame. J Nutr 113: 1851-1860, 1983.

52. Stegink LD, Filer LJ Jr, Baker GL. Plasma glutamate concentrations in adult subjects ingesting monosodium L-glutamate in consomme. Am J Clin Nutr 42: 220-225, 1985.

53. Stoll B, Burrin DG, Henry J, Yu H, Jahoor F, Reeds PJ. Substrate oxidation by the portal drained viscera of fed piglets. Am J Physiol Endocrinol Metab 277: E168-E175, 1999.

54. Toyomasu Y, Mochiki E, Yanai M, Ogata K, Tabe Y, Ando H, Ohno T, Aihara R, Zai H, Kuwano H. Intragastric monosodium L-glutamate stimulates motility of upper gut via vagus nerve in conscious dogs. Am J Physiol Regul Integr Comp Physiol 298: R1125R1135, 2010.

55. Uchiyama C, Mori M, Tatibana M. Subcellular localization and properties of $\mathrm{N}$-acetylglutamate synthase in rat small intestinal mucosa. $J$ Biochem (Tokyo) 89: 1777-1786, 1981.

56. Uneyama H, Niijima A, San Gabriel A, Torii K. Luminal amino acid sensing in the rat gastric mucosa. Am J Physiol Gastrointest Liver Physiol 291: G1163-G1170, 2006.

57. Wu G, Borbolla AG, Knabe DA. The uptake of glutamine and release of arginine, citrulline and proline by the small intestine of developing pigs. $J$ Nutr 124: 2437-2444, 1994.

58. Zai H, Kusano M, Hosaka H, Shimoyama Y, Nagoshi A, Maeda M, Kawamura O, Mori M. Monosodium L-glutamate added to a highenergy, high-protein liquid diet promotes gastric emptying. Am J Clin Nutr 89: 431-435, 2009.

59. Zolotarev V, Khropycheva R, Uneyama H, Torii K. Effect of free dietary glutamate on gastric secretion in dogs. Ann NY Acad Sci 1170: 87-90, 2009. 